\title{
Conceptual Design of Gas Distribution Pipeline Network for Estates in Nigeria
}

\author{
A. A. Adegbola*, I. I. Ozigis, I. D. Muhammad \\ Department of Mechanical Engineering, University of Abuja, FCT Abuja, NIGERIA.
}

\begin{abstract}
This work presents the conceptual design of a gas distribution pipeline network for estates in Nigeria using the University of Abuja Staff Quarters as a case study. The problem statement was the aggressive consumption of cooking gas, referred to as liquefied petroleum gas (LPG), without gas pipeline networks infrastructures to homes and estates across Nigeria but relies on cylinders with its attendant danger. The methodology includes the determination of the gas demand from the average monthly gas consumption in each of the households, the elevation head, diameter of the pipelines, gas velocity, gas mass flow rate, head losses and the pressure drop analysis of series (option 1), parallel (option 2) and grid (option 3) options. The results obtained indicate that the best gas distribution design option for the trunk, reticulation and service pipelines was the grid connections to minimize investment costs with equitable pressures at service outlets. In the selected design option, the total length of the 50.8 $\mathrm{mm}$ diameter trunk pipelines was $19.52 \mathrm{~m}$, while the total length of the $12.7 \mathrm{~mm}$ diameter reticulation and service pipelines were 3,223.34 $\mathrm{m}$ and 1,648.46 $\mathrm{m}$ respectively. The quantities of fittings required for the pipeline network layout were determined for an estate of 124 houses. The mass flow rates of the LPG in the 3 pipeline sections were found to be $0.39 \mathrm{~kg} / \mathrm{s}$ and total head loss based on local resistance coefficients was found to be lowest in option 3 $(1,568.33 \mathrm{~m})$, which also has the least pressure drop of $67.84 \mathrm{kPa}$ in the trunk and reticulation pipelines. It can be concluded that the optimized design could be adopted for the gas distribution pipeline network of University of Abuja staff quarters and other estates in Nigeria, with similar elevation and buildings layout.
\end{abstract}

Keywords: liquefied petroleum gas, gas distribution, distribution networks, frictional head losses

\section{INTRODUCTION}

Liquefied petroleum gas is a combination of combustible hydrocarbon gases (e.g. propane, butane, isobutane), which could be utilized for heating and cooking in homes and when compressed as fuel for cars, vehicles and generators [1]. LPG originates from oil and gas wells and processed. For safety reason and in view of the fact that LPG is usually odourless, small amounts of a pungent gas such as ethane-thiol (or ethyl mercaptan) are added to help people perceive gas leaks [2].

In Nigeria, availability of gas fuels for household and industrial usages has been projected to last as long as 500 years [1,2]. Similarly, natural gas (NG) has been adjudged as a source of energy for future use, with capability to play important role in meeting energy demands in Nigeria and other countries at large. The NG reserves in Nigeria, which has been estimated to be in excess of 185 trillion cubic feet, is expected to further boost the growth of the GDP and infrastructural development of the Nigerian economy [3, 4]. No doubt,

\footnotetext{
${ }^{*}$ Corresponding author (Tel: +234 (0)806 761 2047)

Email addresses: remzy88@gmail.com (A. A. Adegbola), idris.ozigi@uniabuja.edu.ng (I. I. Ozigis), d.ibrahim@uniabuja.edu.ng (I. D. Muhammad)
}

energy demand in Nigeria especially for domestic and industrial uses has continued to grow due to rising population, enhanced standard of living and growth of medium scale industries [5].

Even though there has been considerable achievement in the transmission and utilization of gas for power generation in Nigeria, in which some pipeline had capacity up to $5.66 \mathrm{~m}^{3}$ and 0.15 - $0.61 \mathrm{~m}$ diameter with overall length of 1,205 $\mathrm{km}$. The transmission of LPG (also called cooking Gas (CG)) from wellheads to pump stations and its subsequent distribution to households to serve as fuel for cooking and other household purposes has been a serious problem to the government and citizens of Nigeria. In order to make LPG available for consumption by Nigerian households, there is need for an efficient transmission and distribution network of pipelines with consideration for variables like length and diameter of pipes, inlet and discharge pressures, temperature and interval between compressor stations [6]. In order to achieve safe operations of the distribution lines, the LPG is typically set to operate at pressures between $3.447 \mathrm{kPa}$ and $1.379 \mathrm{MPa}$ [7]. The lack of gas pipeline distribution network system in Abuja has posed a serious challenge to the safe use of natural gas in homes. Also, the rising trend in 
the potential dangers of using gas cylinders, has made it imperative to encourage gas distribution to buildings and estates across Nigeria through gas pipeline network supply into homes. This is a major challenge that this work intends to address in order to make the cooking gas more accessible and affordable to residents of University of Abuja staff quarters in Giri, Abuja, Nigeria, which is located at longitude $9.00^{\circ} \mathrm{N}$ and latitude $7.07^{\circ} \mathrm{E}$.

The aim of this study is to conceptually design a gas pipeline distribution network for estates in Nigeria using University of Abuja Staff Quarters, Giri, Abuja as a case study. The objectives of this study include determination of gas demand, determine gas mass flow rates in the distribution (or trunk, reticulation and service) pipelines as well as to determine pressure losses on three design options and select the best design.

\section{LITERATURE REVIEW}

The absence of an efficient transmission and distribution pipeline network systems that could enhance consumption of this abundant natural energy resource for residential usage has resulted in wastage of valuable energy resource. The Nigeria Extractive Industry Transparency Initiative (NEITI) in its Oil and Gas Audit report [8] attributed the decline in the volume of gas flared to increase in gas sales, which can be further reduced or totally eliminated with utilization of the gas for domestic purposes.

The annual energy outlook carried out in 2014 with projections to 2040 indicated that there will be considerable increase in energy consumption due to upsurge in the desire for improved standard of living and increased world population [9]. According to the 2006 census conducted by the $\mathrm{Na}$ tional Population Commission (NPC), the population of the Abuja, Nigeria, was 1,406,239 [10]. The projected population for the Abuja, Nigeria, as at 2011 was estimated to be $2,238.751$, which is a $59.2 \%$ growth rate over a period of five (5) years [11]. It is expected that the population of the Abuja, Nigeria, would have grown to about $3,564.121$ and 5,674,127 in 2016 and 2021, respectively.

The National Bureau of Statistics according to its 2012 report indicated that as at $2010,6.3 \%$ [10] of the households in Abuja made us of gas as a source of energy for cooking while $62.4 \%$ [10] depended on wood as the source of energy for cooking. It is expected that the utilization of gas which is a cleaner source of energy for cooking will considerably increase upon full implementation of the efficient gas transmission and distribution network that will take cooking gas to the door steps of the consumers and minimize the risks associated with the use of gas cylinders in homes. Also, the current trend in the growth rate of the population of the Abuja, Nigeria and the high level of rural-urban migration is an indication of ready market for the gas as there will be higher demand for energy like cooking gas.

A researcher [12] conducted a study on households' access and preference to cooking fuels in
Abuja and concluded that among the fuels evaluated (firewood, electricity, charcoal, kerosene and cooking LPG), firewood was the most accessible and preferable while cooking gas was the least accessible and preferable [12]. However, the 1,205 $\mathrm{km}$ gas pipeline attained is insignificant to what is needed to make the cooking gas more accessible and affordable to Nigerian cities including residents of University of Abuja staff quarters in Giri, Abuja, Nigeria.

Gas pipeline distribution networks comes in the form of series, parallel, grid, ring and radial connections system [13, 14]. Distribution pipelines had subdivisions as trunk, reticulation and service lines. Series pipeline network implies connections of two or more pipes in such a way that fluid flow follows a single path throughout the system. In practice, series may be connected with few parallels. The series pipeline is easy to lay but in event of failure, it will be difficult to supply gas to affected area ahead, including low pressure at the tail end. Parallel pipeline is a combination of two or more reticulation pipes connected to main trunk lines and also obtain gas flow from the main trunk lines. In practice, parallel may have few series connections in its system. The parallel pipeline system increases cost of pipelines and fittings including valves but have improved pressure at service outlets than series pipeline system. Grid pipeline networks implies that the main trunk, reticulation and service pipes are interconnected to each other. Grid system has increased pipelines and number of valves that helps in equitable gas pressure at service outlets and not seriously affected in event of pipeline failure as the system has more than one supply sources. Ring pipeline system is enclosed by main trunk pipelines in circular shape and some areas can also be enclosed by reticulation pipelines. In event of failure, small area will be affected as there are more than one supply sources but with lower reliability due to higher number of valves than other networks. Radial pipeline network system has its gas storage tank in the middle of the estate while the trunk lines spread-out radially towards the periphery service pipelines. The radial network is limited by the degree of accident severity in event of gas tank failure.

In Nigerian households, the major energyconsuming activities include cooking, lighting, and use of electrical appliances. A researcher found out that cooking activities account for an overwhelming percentage of about $91 \%$ of household energy consumption, lighting uses up to $6 \%$, and the remaining $3 \%$ is attributable to the use of basic electrical appliances such as televisions and pressing irons [15].

\section{METHODOLOGY}

\subsection{Gas Demand}

Liquefied Petroleum Gas (LPG) is the gas that will be distributed to the households in the University of Abuja Staff Quarters at Giri, Abuja (UASQ), while a $1.0 \mathrm{~kW}$ table top cooker burner was selected for use at each of the household. The 
properties of LPG and the characteristics of 1.0 kW burner were as contained in Tables A.13 and A.14, respectively. A table top cooker rated at 1.0 $\mathrm{kW}$ table top cooker burner (Model CG.1 4G) by Teka eka Industrial, SA, was selected for use at each of the household as shown in Table A.14 [16]. The gas demand was determined through the gas fuel consumption rate as stated by the burner manufacturer, period for each cooking, number times of cooking per day and the number of days in a month, primarily derived from Tables A.13 and A.14.

The monthly gas demand for the estate $\left(Q_{m}\right)$ was determined using Eq. (1):

$$
Q_{m}=A_{g} \times T_{c} \times N_{c} \times D_{m} \times X_{h}
$$

Where $A_{g}$ is the average gas consumption rate by use of $1.0 \mathrm{~kW}$ capacity burners [16], in the households $(\mathrm{kg} / \mathrm{hr}) . T_{c}$ is the time for cooking and boiling water (hrs) [17], $N_{c}$ is the number of cooking and boiling water in a day, $D_{m}$ is the number of days in a month (days) and $X_{h}$ is the number of households in the estate. The estimated gas consumption was used to determine the required capacity of the LPG storage.

\subsection{Design of Gas Pipeline Network}

Three (3) pipeline distribution layouts were developed for the staff quarters using the generated layout map of the staff quarters on as the basis, which mostly are dependent on gradient, optimum route, avoidance of sharp edges, costs, quantity and quality of gas at service outlets. Series, parallel and grid connections were evaluated as option 1 , option 2 and option 3 , respectively.

\subsubsection{Elevation head}

The head depends on suction lift which is the vertical distance from the lower storage vessel level to the pump axis and delivery lift which is vertical distance from the pump axis to the delivery pipe outlet.

Elevation head for inclined pipeline was calculated using Eq. (2) [18]:

$$
H_{e l}=h_{s} \sin \alpha_{s}+h_{d} \sin \alpha_{d}
$$

Where $h_{s}$ is the vertical height of the trunk pipe from the storage vessel to the pump axis $(\mathrm{m}), h_{d}$ is the vertical height of service pipe to the connection points of the burners (m) and $\alpha_{s}$ is the inclination angle of the reticulation and service pipes to the horizontal $\left({ }^{\circ}\right)$.

\subsubsection{Trunk, reticulation and service pipelines di- ameter}

The service pipe diameter (D) was calculated using Eq. (3) and (4) [18]:

$$
D=k \times 0.0131 Q_{p}^{0.467}
$$

where $Q_{p}$ is the gas demand ( $\mathrm{m}^{3} /$ day), $k$ is a coefficient depending on the number of delivery pipes and $D$ is the pipe diameter $(\mathrm{mm})$.
The inner diameter $(d)$ of the pipes was calculated using Eq. (4) [18] below:

$$
d=D-2 T
$$

Where: $T$ is the thickness of the pipe $(\mathrm{mm})$.

\subsubsection{Gas flow through pipes}

Gas velocities in the trunk pipe sections:

The gas velocity in the trunk lines was calculated using Eq. (5) [18]:

$$
V_{T}=\frac{4 Q_{T}}{\pi d_{T}^{2}}
$$

where $Q_{T}$ is the gas demand ( $\mathrm{m}^{3} /$ day), $d_{T}$ is the trunk pipe inner diameter $(\mathrm{m})$ and $V_{T}$ is the gas velocity in trunk pipe $(\mathrm{m} / \mathrm{s})$. The gas velocities in the reticulation and service pipelines were computed as in Appendix B.

\subsubsection{Mass flow rate of gas in pipeline networks (m)}

Gas mass flow rate in the trunk pipe sections: The gas mass flow rate in the trunk pipelines $\left(m_{T}\right)$ was calculated using Eq. (6) [19]:

$$
m_{T}=\rho A_{T} V_{T}
$$

Where $\rho$ is the gas density $\left(\mathrm{kg} / \mathrm{m}^{3}\right), V_{T}$ is the gas velocity in trunk pipe $(\mathrm{m} / \mathrm{s})$ and $A_{T}$ is the trunk pipe area $\left(\mathrm{m}^{2}\right)$. The gas mass flow rates in the reticulation and service pipelines were computed as in Appendix B.

\subsubsection{Frictional head loss in pipeline networks}

When gas flows in a pipe, it experiences resistance to its motion, due to which its velocity and ultimately the head of gas available is reduced. The major losses experienced are the losses due to friction, which was determined using the DarcyWelsbach formula stated in Eq. (7) [20].

$$
h_{f}=\frac{f L V^{2}}{d \times 2 g}
$$

Where $h_{f}$ is the frictional head loss $(\mathrm{m}), f$ is the co-efficient of friction (a function of Reynolds number, $R_{e}$ )

$$
\begin{aligned}
& f=\left\{\begin{array}{l}
\frac{0.0791}{\left(R_{e}\right)^{\frac{1}{4}}} \text { for } R_{e} \text { varying from } 4000 \text { to } 10^{6} \\
\frac{16}{\left(R_{e}\right)^{\frac{1}{4}}} \text { for } R_{e}<2000 \text { (laminar/viscous flow) }
\end{array}\right. \\
& R_{e}=\frac{V \times d}{v}
\end{aligned}
$$

where $V$ is the mean velocity of flow $(\mathrm{m} / \mathrm{s}), v$ is the kinematic viscosity (stoke), $d$ is the inner diameter of pipe $(\mathrm{mm})$ and $L$ is the length of pipe $(\mathrm{m})$. Eq. (7) was used to compute the head losses in the trunk, reticulation and service pipe for the 3 options. 
3.2.6. Head loss based on local resistance coeffcients

(i) Head loss based on local resistance coefficients in the trunk pipeline (options) [21]

$$
\Sigma h_{T}=\left(\lambda_{T} \frac{l_{T}}{d_{T}}+\Sigma \varsigma\right) \frac{V_{T}^{2}}{2 g}
$$

where: $\lambda_{T}$ is the inverse of friction head loss in trunk pipe $\left(\mathrm{m}^{-1}\right)$ i.e. $\lambda_{T}=1 / h_{f} . d_{T}$ is the trunk pipe inner diameter $(\mathrm{m}), V_{T}$ is the gas velocity in trunk pipe $(\mathrm{m} / \mathrm{s}), \varsigma$ is local resistance coefficients obtained from trunk pipe layout and fittings, $l_{T}$ is the length of trunk pipe in the network (m), $h_{T}$ is the local resistance coefficient in the trunk pipe (m) and $g$ is the acceleration due to gravity $\left(\mathrm{m} / \mathrm{s}^{2}\right)$. Equation (8) was used to compute the head losses based on local resistances in the distribution (or trunk, reticulation and service) pipelines for the 3 options.

\subsubsection{Storage vessel and pressure drop in pipelines}

(i) Storage Vessel

The gas in above-ground bulk storage vessel was as shown in Fig. 1.

\section{(ii) Pressure drop in pipelines}

The general flow equation (or fundamental flow equation) for the steady-state isothermal flow in the gas pipeline was the basic equation for relating the pressure drop with flow rate. The equation was given in terms of the pipe diameter, gas properties, pressures, temperatures, and flow rate. The General Flow Equation [21]:

$$
Q=\frac{1.1494}{10^{3}}\left[\frac{T_{b}}{P_{b}}\right]\left[\frac{\left(P_{1}^{2}-P_{2}^{2}\right)}{G \cdot T_{f} \cdot L \cdot Z \cdot f}\right]^{0.5} d^{2.5}
$$

where $Q$ is the gas flow rate at standard conditions ( $\mathrm{m}^{3} /$ Day), $L$ is the pipe segment length $(\mathrm{km})$, $d$ is the pipe inner diameter $(\mathrm{mm}), T_{f}$ is the average gas flowing temperature $(\mathrm{K}), Z$ is the gas compressibility factor at the flowing temperature (dimensionless), $f$ is the friction factor (dimensionless), $G$ is the gas gravity (dimensionless), $T_{b}$ is the base temperature (K), $P_{b}$ is the base pressure $(\mathrm{kPa}), P_{1}$ is the upstream pressure $(\mathrm{kPa}), P_{2}$ is the downstream pressure $(\mathrm{kPa})$.

This work assumed that the gas flow process was isothermal, horizontal pipeline, changes in kinetic energy were negligible, no mechanical work done by or on the gas and that the flow was in steady-state. Pressure drop estimation using the general flow equation was computed as follows:

$$
\begin{array}{r}
P_{2}^{2}=P_{1}^{2}-\left[\frac{Q P_{b}}{1.1494 \times 10^{-3} \times T_{b} \times d^{2.5}}\right]^{2} \\
\times G \cdot T_{f} \cdot L \cdot Z \cdot f
\end{array}
$$

Where $Q$ is the gas flow rate at standard conditions ( $\mathrm{m}^{3} /$ Day), $L$ is the pipe segment length $(\mathrm{km})$, $d$ is the pipe inner diameter $(\mathrm{mm}), T_{f}$ is the average gas flowing temperature $(\mathrm{K}), Z$ is the gas compressibility factor at the flowing temperature (dimensionless), $f$ is the friction factor (dimensionless), $G$ is the gas gravity (dimensionless), $T_{b}$ is the base temperature (K), $P_{b}$ is the base pressure $(\mathrm{kPa}), P_{1}$ is the upstream pressure $(\mathrm{kPa})$ and $P_{2}$ is the downstream pressure $(\mathrm{kPa})$.

\subsubsection{Pump head and calculation of motor power}

The pump head and motor power were computed as in Appendix B.

\subsubsection{Selection of optimum design}

Pressure drop analysis was carried out on the three (3) designs of the pipeline distribution network for the University of Abuja Staff Quarters and the design option with the least pressure drop was selected.

\section{COMPUTING PROCEDURE}

Equations (1) to (10) were computed using Microsoft Excel Spreadsheet (2007). Using Eq. (1), the monthly gas demand $\left(\mathrm{m}^{3} / \mathrm{month}\right)$ was computed as follows: Enter the input values into cells C5 to G5. In cell H5, type "=C5*D5*E5*F5*G5" to get $\mathrm{kg} / \mathrm{month}$. To obtain the demand in $\mathrm{m}^{3} /$ day, in cell I5, type "=H5*46452" to get BTU/month; in J5 type "=I5/1000" to get SCF/month; in cell $\mathrm{K} 5$, type "=J5/F5" to get SCF/Day and in cell L5, type "=(K5/0.0283)" to get $\mathrm{m}^{3} /$ day. Eq. (6), was used to obtain the gas mass flow rate in the reticulation pipelines by computation using the excel spreadsheet as follows: Input the values of density into cell G43, values of inner diameter of the reticulation pipe and gas velocity in the reticulation pipe into cells $\mathrm{H} 21$ and $\mathrm{C} 33$ respectively. In C52, type "=G43*3.142*(H21^2)*C33/4" to obtain the gas mass flow rate in the reticulation pipeline. Also, Eq. (7) was used to calculate the head losses in the reticulation pipe section for the three (3) design options as follows: For option 1, enter the necessary values into cells $\mathrm{C} 65$ to $\mathrm{G} 65$. In cell H65, type "=F65*C65/G65" to get $\mathrm{R}_{e}$; in cell, I65, type "=0.0791/(H65)^ $0.25 "$ to get $\mathrm{f}$; in cell J65, type $\left."=\left((4 * \mathrm{I} 65 * \mathrm{E} 65 *(\mathrm{~F} 65))^{*} 2\right) /\left(\mathrm{C} 65^{*} 2 * \mathrm{D} 65\right)\right) "$ to get the head loss due to friction in the reticulation pipe for option 1 and repeat the process for options 2 and 3 as well as the other equations in this work. The computation for the pressure loss in the reticulation line section was carried out and repeated for all the sections in the three (3) options using the Excel software.

\section{RESULTS AND DISCUSSION}

\subsection{Gas Demand}

The monthly gas demand for each household in the estate was found to be $12.6 \mathrm{~kg} / \mathrm{month}$, while for the entire estate were presented in Table 1 . From Table 1, the daily consumption of LPG by households in UASQ was found to be $68.46 \mathrm{~m}^{3}$ and $52.08 \mathrm{~kg}$ in terms of volume and weight, respectively. This translates to $24,647.01 \mathrm{~m}^{3}(18,748.80$ 


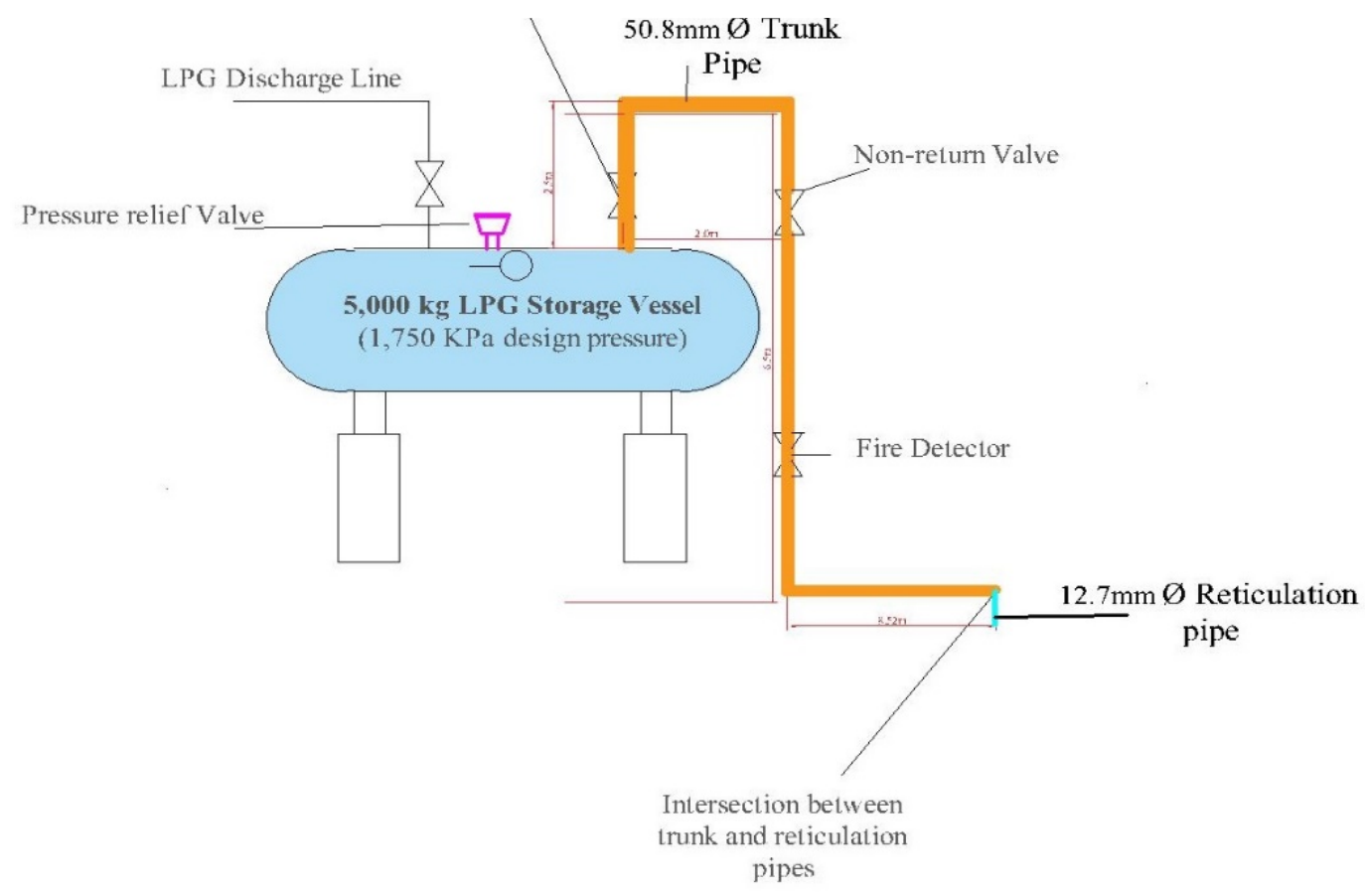

Figure 1: Schematic diagram of the LPG storage vessel showing connection of the trunk pipeline to the LPG vessel and the reticulation pipeline.

$\mathrm{kg}$ ) per annum. The auxiliary burner of $1 \mathrm{~kW}$ selected for use in the estate is similar to camp gas and table top burners available in Abuja. The result of $12.6 \mathrm{~kg} / \mathrm{month} /$ household obtained in this work is similar to the bio-gas demand as was determined by Ozigis, et al. [17]; hence the estimated gas demand for the estate can be said to be realistic and reliable.

Table 1: Gas demands for the UASQ.

\begin{tabular}{lll}
\hline $\begin{array}{l}\text { Gas } \\
\text { Demand }\end{array}$ & Volume & Weight \\
\hline Daily & $68.46 \mathrm{~m}^{3} /$ day & $52.08 \mathrm{~kg} /$ day \\
Monthly & $2,053.92 \mathrm{~m}^{3} /$ month & $1,562.40 \mathrm{~kg} /$ month \\
Yearly & $24,647.01 \mathrm{~m}^{3} /$ year & $18,748.80 \mathrm{~kg} /$ year \\
\hline
\end{tabular}

\subsection{Design of Gas Pipeline Network}

\subsubsection{Elevation head $\left(H_{e i}\right)$}

Elevation head for inclined pipeline was computed using Eq. (2) [18] and found to be 0.04 $\mathrm{m}$. This elevation head is not significant as some heads reach up $10 \mathrm{~m}$ and above in water reticulation [16].

\subsubsection{Diameter of trunk, reticulation and service pipes}

The diameter of the trunk, reticulation and service pipes were compared with industry standards. The trunk pipes had $50.8 \mathrm{~mm}$ in outer diameter while inner diameter was $47.8 \mathrm{~mm}$. The service and reticulation pipes were determined to be $12.7 \mathrm{~mm}$ in outer diameter with $9.7 \mathrm{~mm}$ inner diameter. The thickness of all the pipes was $1.5 \mathrm{~mm}$. The diameter values for the distribution pipes were as in Table 2. The diameter of the pipelines is relevant in the selection of fittings as recommended by [15] and [18].

Table 2: Specifications for trunk, reticulation and service pipes.

\begin{tabular}{llll}
\hline $\begin{array}{l}\text { Pipeline } \\
\text { network }\end{array}$ & $\begin{array}{l}\text { Outer } \\
\text { diameter }\end{array}$ & Thickness $\begin{array}{l}\text { Inner } \\
\text { diameter }\end{array}$ \\
\hline Trunk & $50.8 \mathrm{~mm}$ & $1.5 \mathrm{~mm}$ & $47.8 \mathrm{~mm}$ \\
Reticulation & $12.7 \mathrm{~mm}$ & $1.5 \mathrm{~mm}$ & $9.7 \mathrm{~mm}$ \\
Service & $12.7 \mathrm{~mm}$ & $1.5 \mathrm{~mm}$ & $9.7 \mathrm{~mm}$ \\
\hline
\end{tabular}

\subsubsection{Gas flow velocity and mass flow rates through pipes}

The velocity of gas in the service and reticulation pipelines was found to be $10.72 \mathrm{~m} / \mathrm{s}$ largely due to the fact that both service and reticulation pipelines are of the same diameter. The velocity of the gas in the trunk pipeline, which was of larger diameter, was found to be considerably lower than that of service and reticulation pipelines (Table $3)$. The velocities of LPG in the pipelines sections were comparable to the burner reported to be 10 $\mathrm{m} / \mathrm{s}[16,19]$. The mass flow rates in the trunk, reticulation and service pipelines was found to be $0.39 \mathrm{~kg} / \mathrm{s}$, which implies uniform mass flow rate of the LPG in all the pipeline sections. The mass flow rate of the LPG in the pipelines sections was compared to that of a burner reported to be 0.67 $\mathrm{kg} / \mathrm{s}$ [19]. This differences in mass flow rates will result incorporation of throat valve.

\subsubsection{Frictional head loss in pipeline networks}

From Table 4, it could be seen that the least head loss due to friction was in the trunk pipe 
Table 3: Gas velocity in the trunk, reticulation and service pipelines.

\begin{tabular}{ll}
\hline Pipeline network segment & Gas Velocity $(\mathbf{m} / \mathbf{s})$ \\
\hline Trunk & 0.44 \\
Reticulation & 10.72 \\
Service & 10.72 \\
\hline
\end{tabular}

sections and is the same, because the length and diameter of the trunk pipe sections were similar. The total head loss due to friction in the trunk pipeline sections were $62,306.70 \mathrm{~m}, 62,165.75 \mathrm{~m}$ and $59,364.58 \mathrm{~m}$ for options 1,2 and 3 , respectively. Option 3 could be said to be the most preferable due to friction.

Table 4: Frictional head losses in the trunk, reticulation and service pipelines.

\begin{tabular}{llll}
\hline Pipeline & \multicolumn{3}{c}{ Gas velocity $(\mathrm{m} / \mathbf{s})$} \\
network & Option 1 & Option 2 & Option 3 \\
segment & Opme & 0.1172 & 0.1172 \\
Trunk & 0.1172 & 0.1172 & $39,954.18$ \\
Reticulation & $42,659.39$ & $42,578.37$ & 39,4 \\
Service & $19,647.19$ & $19,587.26$ & $19,410.28$ \\
Total & $62,306.70$ & $62,165.75$ & $59,364.58$ \\
\hline
\end{tabular}

\subsubsection{Head loss based on local resistances in the pipelines}

The local resistance coefficients for LPG for 10$50 \mathrm{~mm}$ passage diameter for the fittings (ball, 3-way manifold and fire-detector valves; elbow, union and tee joints) were obtained from Table 5 . The trunk, reticulation and service connection fittings were as shown in Tables 6 - 8 .

The local resistances reflect the number and types of fittings in the pipeline networks were as shown in Table 9. From Table 9, it could be seen that the least head loss based on local resistance was in the trunk pipe sections and was the same because the length and diameter of the trunk pipe sections were the same. The total head loss based on local resistances in the three (3) pipeline sections were $1,578.20 \mathrm{~m}, 1,567.45 \mathrm{~m}$ and $1,568.33 \mathrm{~m}$ for options 1, 2 and 3 respectively. Option 3 could be said to be the most preferable in terms of head loss.

\subsubsection{The storage vessel and pressure drop in gas trunk, reticulation and service pipelines \\ Storage vessel}

The discharge of the gas will be such that the storage vessel was within 30 meters from the point of discharge and the driver must have line of sight between the tanker and the storage vessel [21]. The LPG was expected to flow by natural drive from the storage vessel where it will be stored in liquid form at a pressure of 1,750 $\mathrm{kPa}$ and through the use of valves and pressure regulators, gas will be delivered to the service pipe close to the buildings at a pressure of 34.47 $\mathrm{kPa}[19]$ and then to the appliances in gaseous form at an operating pressure of $2.74 \mathrm{kPa}$ [22].
The Schematic diagram of the LPG storage vessel showing connection of the trunk pipeline to the LPG vessel and the reticulation pipeline was shown in Fig. 1.

\section{Pressure drop in trunk, reticulation and service pipelines}

The pressure drop estimation for the three (3) options was computed for the trunk and reticulation pipe sections. The trunk pipelines began from Section Y-X, W-V and X-W in Options 1, 2 and 3 respectively: The result indicated that there was no pressure loss between points V (upstream) and U (downstream) of the Trunk line. The pressure remains the same at $1,750 \mathrm{kPa}$. This was attributed to the fact that the length of the trunk pipeline was not significant to cause a pressure drop in the pipeline section. The reticulation pipelines began from Section X-A, V-A and W-A in Options 1, 2 and 3 respectively. In option 1, the total pressure drops in the trunk and reticulation pipeline sections was found to be 82.54 $\mathrm{kPa}$; in option 2 , the total pressure drops in the trunk and reticulation pipeline sections was found to be $85.13 \mathrm{kPa}$, while in option 3 , the total pressure drops in the trunk and reticulation pipeline sections was found to be $67.84 \mathrm{kPa}$. Considering the pressure drops in the trunk and reticulation pipeline sections for the three (3) options, it could be seen that option 1 has the highest pressure drop while option 3 has the least pressure drop. The pressure drop in these options is not significant which eliminates the need for the use of pumps. However, in the case of commercial gas plants operators, pumps and motors are needed as the LPG must be transferred from the storage vessel to customers' cylinders in liquid form and at a pressure above the bubble point pressure of the LPG. Details of the pressure drops in trunk and reticulation pipe sections for option 3 are contained in Table 10.

Pressure drop were carried out on service pipelines for three (3) houses (Houses 48, 124 and 128) in option 3 . From the results obtained, it could be seen that there is no significant pressure drop from various points on the reticulation lines to the house. This implies that pressure regulators with capacity to withstand pressure beyond $1,700 \mathrm{kPa}$ and that can deliver gas to the burner at the required pressure must be deployed to all the houses (Fig. 2). Details of the results are contained in Table 11.

\section{Selection of optimal design}

Pressure drop analysis was carried out on the three (3) designs of the pipeline distribution network for the University of Abuja Staff Quarters were as presented in Table 12 .

From Table 12, in the trunk, reticulation and service pipelines, option 1 has the highest values in terms of reticulation pipe length, total head loss due to friction, total head loss based on local resistance coefficients, pump head, motor power and pressure drop. Option 2 has the highest value in terms of the service pipe length, while options 1 
Table 5: Coefficient of local resistances [18, 19].

\begin{tabular}{|c|c|c|c|}
\hline Fitting or shaped piece & $\begin{array}{l}\text { Passage diameter, } d_{e q} \\
(\mathrm{~mm}) \text { for water }[18]\end{array}$ & $\begin{array}{l}\text { Local resistance coef- } \\
\text { ficient (water) [18] }\end{array}$ & $\begin{array}{l}\text { Local resistance coeffi- } \\
\text { cient (LPG) for } 10-50 \mathrm{~mm} \\
\text { passage diameter [19] }\end{array}$ \\
\hline $\begin{array}{l}\text { Wedge gate valve with slid- } \\
\text { ing spindle }\end{array}$ & $80-400$ & 0.26 & \\
\hline Ball valve, fully open & & & 0.05 \\
\hline 3-way manifold valves & & & 0.05 \\
\hline Gate valve & & & 0.15 \\
\hline $\begin{array}{l}\text { Non return (check) valve, } \\
\text { forward flow }\end{array}$ & $80-400$ & 10 & 2.0 \\
\hline Fire detector valve & & & 2.0 \\
\hline Inlet strainer with valve & $\begin{array}{l}100 \\
150 \\
200 \\
250 \\
300\end{array}$ & $\begin{array}{l}7.0 \\
6.0 \\
5.2 \\
4.5 \\
3.7\end{array}$ & \\
\hline $\begin{array}{l}\text { Long radius threaded }-90^{\circ} \\
\text { elbow }\end{array}$ & $80-300$ & 0.6 & 0.7 \\
\hline $\begin{array}{l}\text { Union threaded } \\
\text { Line flow threaded tee } \\
\text { Diffuser } \\
\text { Contraction }\end{array}$ & $\begin{array}{l}80-300 \\
d_{1} / d_{2}=0.5-0.8 \\
d_{1} / d_{2}=1.2-1.65\end{array}$ & $\begin{array}{l}1.5 \\
0.25 \\
0.4\end{array}$ & $\begin{array}{l}0.08 \\
0.9\end{array}$ \\
\hline
\end{tabular}

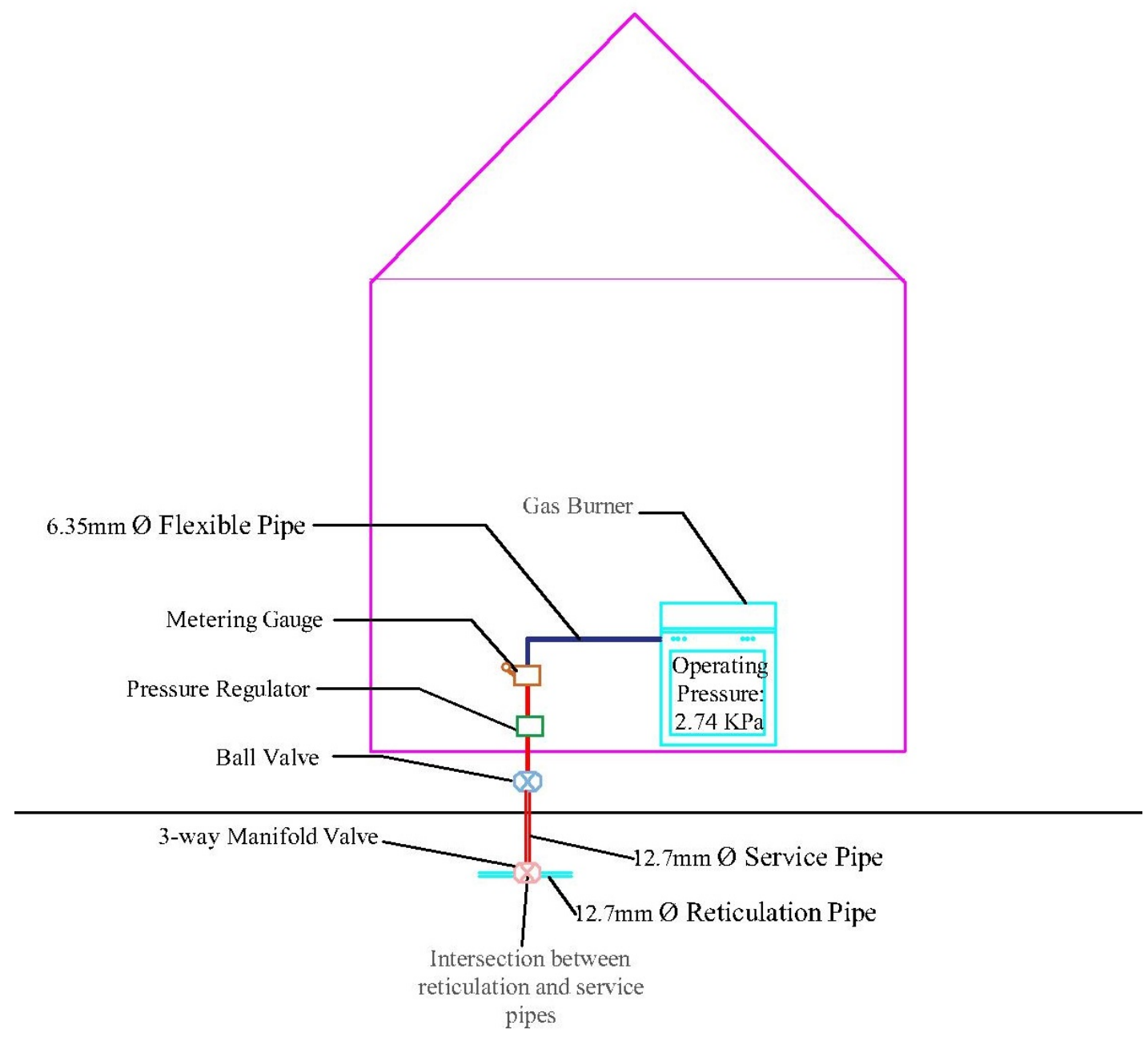

Figure 2: LPG connection from service pipeline to gas burner with fittings. 
Table 6: Local resistance coefficients for the trunk pipes fittings.

\begin{tabular}{lccc}
\hline Type of fittings & Number & $\begin{array}{c}\boldsymbol{\varsigma} \text { per } \\
\text { fitting [19] }\end{array}$ & $\boldsymbol{\Sigma}$ \\
\hline Elbows & 4 & 0.7 & 2.8 \\
Union threaded & 2 & 0.08 & 0.16 \\
Tees return/control & 0 & 0.9 & 0.0 \\
Non volves & 2 & 2.0 & 4.0 \\
valve detector valves & 1 & 2.0 & 2.0 \\
Ball valves & 0 & 0.05 & 0.0 \\
Gate valves & 0 & 0.15 & 0.0 \\
& Total & & 8.96 \\
\hline
\end{tabular}

Table 7: Local resistance coefficients for the reticulation pipes fittings - Option 3.

\begin{tabular}{lccc}
\hline Type of fittings & Number & $\begin{array}{c}\boldsymbol{c} \text { per } \\
\text { fitting [19] }\end{array}$ & $\boldsymbol{\Sigma}$ \\
\hline Elbows & 9 & 0.7 & 6.3 \\
Union threaded & 15 & 0.08 & 1.2 \\
Tees & 27 & 0.9 & 24.3 \\
Non return valves & 2 & 2.0 & 4.0 \\
Fire detector valves & 2 & 2.0 & 4.0 \\
3-way manifold valves & 124 & 0.05 & 6.2 \\
Gate valves & 0 & 0.15 & 0.0 \\
& Total & & 46.0 \\
\hline
\end{tabular}

and 3 have the same lengths for the service pipes. In the trunk, reticulation and service pipelines, option 3 was found to have the lowest values in terms of reticulation pipe length, total head loss due to friction, total head loss based on local resistance coefficients and pressure drop. Option 3 is considered the best and selected for cost analysis.

The series gas distribution pipeline network layout (option 1), the parallel gas distribution pipeline network layout (option 2) and the grid gas distribution pipeline network layout (option 3) were presented as in Figs. 3, 4 and 5 respectively.
Table 8: Local resistance coefficients for the service pipes fittings.

\begin{tabular}{lccc}
\hline Type of fittings & Number & $\begin{array}{c}\boldsymbol{c} \text { per } \\
\text { fitting [19] }\end{array}$ & $\boldsymbol{\Sigma}$ \\
\hline Elbows & 248 & 0.7 & 173.6 \\
Union threaded & 0 & 0.08 & 0 \\
Tees & 0 & 0.9 & 0 \\
Non return valves & 0 & 2.0 & 0 \\
Fire detector valves & 0 & 2.0 & 0 \\
Ball valves & 124 & 0.05 & 6.2 \\
Gate valves & 124 & 0.15 & 18.6 \\
& Total & & 198.4 \\
\hline
\end{tabular}

Table 9: Local resistance in trunk, reticulation and service pipelines.

\begin{tabular}{lccc}
\hline $\begin{array}{l}\text { Pipeline } \\
\text { work segment- }\end{array}$ & \multicolumn{3}{l}{$\begin{array}{l}\text { Head loss based on local re- } \\
\text { sistance coefficient }\end{array}$} \\
\cline { 2 - 4 } & Option 1 & Option 2 & Option 3 \\
\hline Trunk & 34.46 & 34.46 & 34.46 \\
Reticulation & 330.29 & 319.65 & 320.04 \\
Service & $1,213.45$ & $1,213.30$ & $1,213.83$ \\
Total & $1,578.20$ & $1,567.45$ & $1,568.33$ \\
\hline & & & \\
\hline
\end{tabular}

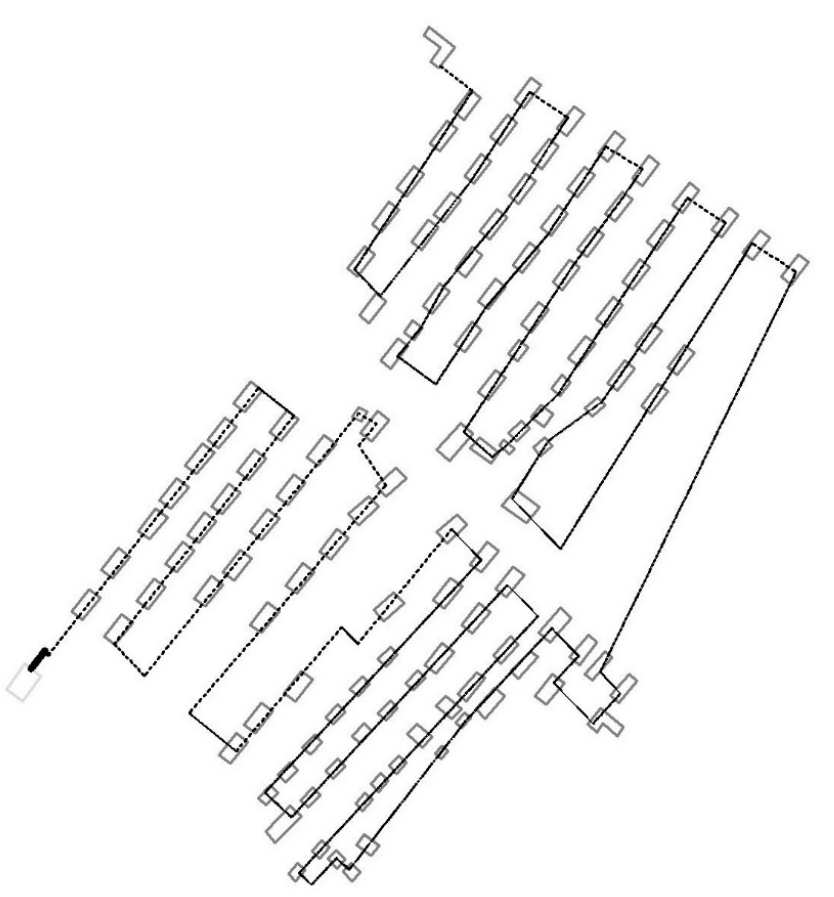

Figure 3: Series Gas distribution pipeline network layout. 


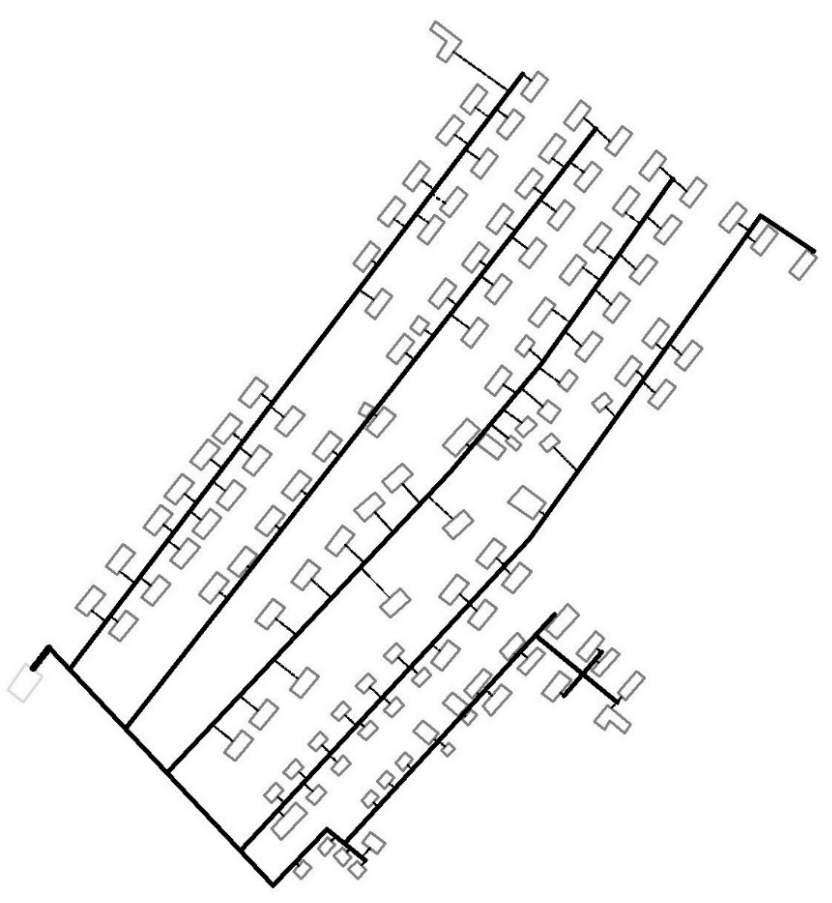

Figure 4: Parallel Gas distribution pipeline network layout.

\section{Pump head and motor power}

The pump head was computed for the 3 design options and found to be $1,578.24 \mathrm{~m}, 1,567.45 \mathrm{~m}$ and $1,568.37 \mathrm{~m}$ for options 1,2 and 3 respectively. Option 3 could be said to be the best as it has the least pump head. The motor power was computed for the 3 design options and found to be $8.64 \mathrm{~kW}, 8.58 \mathrm{~kW}$ and $8.59 \mathrm{~kW}$ for options 1,2 and 3 respectively. The power rating obtained for the entire estate is very low when compared with $5.5 \mathrm{~kW}$ power rating of the electric motors at the gas plants visited. This confirms the fact that no pump is needed as the LPG will flow by natural drive from the storage vessel where it is stored in liquid form at a pressure of $1,750 \mathrm{kPa}$ and through the use of valves and pressure regulators to deliver gas to the service pipelines close to the buildings at a pressure of $34.47 \mathrm{kPa}$ and then to the appliances in gaseous form at an operating pressure of $2.74 \mathrm{kPa}$.

\section{CONCLUSION}

This study was on conceptual design of a gas distribution pipeline network for an estate using the University of Abuja Staff Quarters as a case study. It can be concluded that $12.6 \mathrm{~kg}$ of LPG is required per month per household within the UASQ and that LPG will have a smooth flow through the pipeline network at an average velocity of $10.72 \mathrm{~m} / \mathrm{s}$ and mass flow rate of 0.39 $\mathrm{kg} / \mathrm{s}$ in the service and reticulation pipeline sections. The total head loss due to friction in the 3 pipeline sections were $47,695.39 \mathrm{~m}, 46,511.79$ $\mathrm{m}$ and $44,603.85 \mathrm{~m}$ for options 1,2 and 3 respectively, while the total head loss based on local resistance coefficients were $1,578.20 \mathrm{~m}, 1,567.45 \mathrm{~m}$ and $1,568.33 \mathrm{~m}$ for options 1,2 and 3 respectively, with option 3 having the lowest value. Option 3 had the least pressure drop of $67.84 \mathrm{kPa}$ in the trunk and reticulation pipelines, while options 1 and $2 \mathrm{had}$ higher pressure drops of $82.54 \mathrm{kPa}$ and $85.13 \mathrm{kPa}$ respectively. The computed pump head for the three (3) design options were $1,579.13 \mathrm{~m}$, $1,567.45 \mathrm{~m}$ and $1,568.33 \mathrm{~m}$ for options 1,2 and 3 respectively, while the computed motor power for the 3 design options were $8.64 \mathrm{~kW}, 8.58 \mathrm{~kW}$ and $8.59 \mathrm{~kW}$ for options 1,2 and 3 respectively. It can be concluded that no pump was required to deliver gas to the houses within the estate in view of the low power ratings obtained considering the size of the estate. The LPG will be delivered to houses by natural drive and appropriate pressure regulators shall be installed at the each of the houses. Based on all indicators mentioned above, it can be largely concluded that the best of the design options was option 3.

\section{References}

[1] S. Gupta and A. K. Jain, "Analytical study of natural gas pipeline tarif," Asian Journal of Business and Economics, vol. 2, no. 2.1, pp. 2-4, 2012.

[2] G. Igwe. (2011, July) Natural gas transmission and distribution in nigeria. Daily Trust. [Online]. Available: www.dailytrust.com.ng

[3] (July) Natural gas definition. [Online]. Available: http://naturalgas.org/

[4] O. Omomia. (2016, December) Lpg consumption survey: Assessment of market opportunities and penetration. [Online]. Available: http://www.businessdayonline.com

[5] G. Adedayo, F. Saleh, and O. Koleh, "Rural household wood energy utilization pattern and its impact on deforestation in Akoko-South West L.G.A, Ogun State Nigeria," in 1st National Conference of Forests and Forest Produce Society, Lagos, April 16-18 2008, pp. 15-164.

[6] R. Singh and P. Nain, "Optimization of natural gas pipeline design and its total cost using ga." International Journal of Scientific and Research Publications, vol. 2 , no. 8, pp. 1-10, 2012.

[7] (2016, September) Article on Conceptual Design Vs Detailed Design by Steen Solutions LLC. [Online]. Available: http://steensolutions.com/2016/03/conceptualdesign-vs-detailed-design-in-product-development/

[8] "Financial, Physical and Process Audit: An Independent Report Assessing and Reconciling Physical and Financial Flows within Nigeria's Oil and Gas Industry for the year 2014," Nigeria Extractive Industry Transparency International (NEITI), Tech. Rep., December.

[9] "Annual energy outlook 2014, with projections to 2040," U.S. Energy Information Administration, pp. 121-136 2014, washington, DC: U.S. Department of Energy.

[10] "Annual abstract of statistics report," National Bureau of Statistics, Abuja, Tech. Rep., 2012.

[11] "Greenhouse gas emissions reporting from the petroleum and natural gas industry," U.S. Environmental Protection Agency, Washington, DC, Tech. Rep., 2010.

[12] H. Gujba, Y. Mulugetta, and A. Azapagic, "The household cooking sector in nigeria: Environmental and economic sustainability assessment," Journal Resources, vol. 4, pp. 412-433, 2015.

[13] M. Pradhikaran, "Module-1: Basics of water supply system training module for local water and sanitation management, performance assessments system project," CEPT University Kasturbhai Lalbhai Campus, University Road, Navrangpura, Ahmedabad 380 009 Gujarat, India, pp. 23-24, 2012.

[14] S. Boddu and R. Kumar, "Design and Analysis of Pipe Network System by using Epanet," Manager's Journal on Civil Engineering, vol. 6, no. 2, p. 42, 2016.

[15] U. Akuru and O. Okoro, "Renewable energy investment in Nigeria: A review of the renewable energy master 


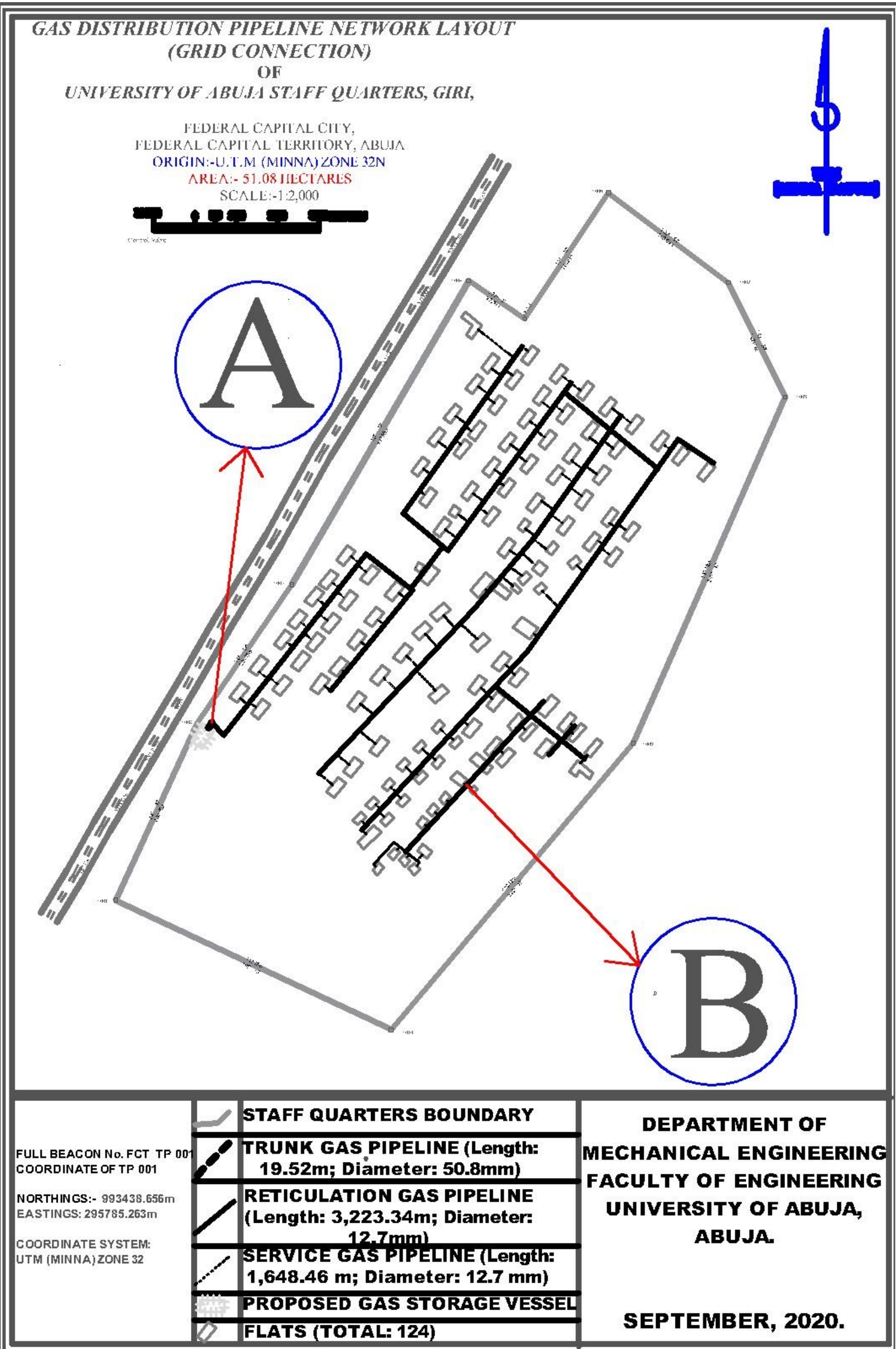

Figure 5: Grid gas distribution pipeline network layout from storage vessel to gas burner. 
Table 10: Pressure drop in trunk and reticulation pipe sections (Option 3).

\begin{tabular}{|c|c|c|c|c|}
\hline Section & $\begin{array}{c}\text { Pipe length } \\
(\mathrm{m})\end{array}$ & $\begin{array}{c}\text { Upstream } \\
\text { pressure (kPa) }\end{array}$ & $\begin{array}{cc}\text { Downstream } \\
P_{1} \text { pressure }(\mathrm{kPa}) P_{2}\end{array}$ & $\begin{array}{l}\text { Pressure drop }(\mathrm{kPa}) \\
\text { Absolute value }\left(P_{2}-P_{1}\right)\end{array}$ \\
\hline $\mathrm{X}-\mathrm{W}$ & 19.52 & 1750.00 & 1750.00 & 0.00 \\
\hline W-A & 22.38 & 1750.00 & 1749.51 & 0.49 \\
\hline$A-B$ & 313.76 & 1749.51 & 1742.70 & 6.82 \\
\hline B-C & 79.97 & 1742.70 & 1740.95 & 1.74 \\
\hline C-D & 176.6 & 1740.95 & 1737.10 & 3.85 \\
\hline C-E & 71.91 & 1740.95 & 1739.39 & 1.57 \\
\hline E-F & 9.51 & 1739.39 & 1739.18 & 0.21 \\
\hline F-G & 78.48 & 1739.18 & 1737.47 & 1.71 \\
\hline $\mathrm{G}-\mathrm{H}$ & 273.44 & 1737.47 & 1731.49 & 5.98 \\
\hline F-I' & 273.44 & 1739.18 & 1733.20 & 5.98 \\
\hline I'-I & 8.9 & 1733.20 & 1733.01 & 0.19 \\
\hline I'-J' & 82.24 & 1733.20 & 1731.40 & 1.80 \\
\hline$J^{\prime}-K$ & 555.55 & 1731.40 & 1719.19 & 12.22 \\
\hline J'-J & 19.54 & 1731.40 & 1730.97 & 0.43 \\
\hline$J^{\prime}-N^{\prime}$ & 83.54 & 1731.40 & 1729.57 & 1.83 \\
\hline N'-N & 41.67 & 1729.57 & 1728.66 & 0.91 \\
\hline N'-M & 312.3 & 1729.57 & 1722.71 & 6.86 \\
\hline M-M' & 63.63 & 1722.71 & 1721.30 & 1.40 \\
\hline M'-P' & 62.64 & 1721.30 & 1719.92 & 1.38 \\
\hline$P^{\prime}-Q$ & 251.19 & 1719.92 & 1714.37 & 5.55 \\
\hline $\mathrm{P}^{\prime}-\mathrm{P}$ & 25.57 & 1719.92 & 1719.36 & 0.56 \\
\hline P'-T' & 54.36 & 1719.92 & 1718.72 & 1.20 \\
\hline $\mathrm{T}^{\prime}-\mathrm{V}$ & 39.57 & 1718.72 & 1717.85 & 0.87 \\
\hline$T^{\prime}-\mathrm{T}$ & 25.91 & 1718.72 & 1718.15 & 0.57 \\
\hline T'-U & 25.91 & 1718.72 & 1718.15 & 0.57 \\
\hline $\mathrm{N}-\mathrm{O}$ & 56.87 & 1728.66 & 1727.41 & 1.25 \\
\hline $\mathrm{Q}-\mathrm{R}$ & 20.43 & 1714.37 & 1713.92 & 0.45 \\
\hline Q-S & 23.7 & 1713.92 & 1713.40 & 0.52 \\
\hline \multirow{2}{*}{\multicolumn{4}{|c|}{$\begin{array}{l}40.99 \\
\text { Total pressure drop (KPa) }\end{array}$}} & 0.91 \\
\hline & & & & 67.84 \\
\hline
\end{tabular}

Table 11: Pressure drop in selected service pipeline sections (Option 3).

\begin{tabular}{lcccc}
\hline Section & $\begin{array}{c}\text { Pipe length } \\
(\text { meters })\end{array}$ & $\begin{array}{c}\text { Upstream } \\
\text { pressure (kPa) }\end{array}$ & $\begin{array}{c}\text { Downstream } \\
\text { pressure }(k P a)\end{array}$ & $\begin{array}{c}\text { Pressure drop }(k P a) \\
\text { Absolute value }\left(\boldsymbol{P}_{2}-\boldsymbol{P}_{\mathbf{1}}\right)\end{array}$ \\
\hline Q-H128 & 4.31 & 1714.37 & 1714.37 & 0.00 \\
H-H124 & 61.94 & 1731.49 & 1730.13 & 1.36 \\
J-H48 & 16.24 & 1730.97 & 1730.62 & 0.36 \\
\hline
\end{tabular}

Table 12: Summary table for pipeline connections options 1, 2 and 3.

\begin{tabular}{|c|c|c|c|}
\hline & Option 1 & Option 2 & Option 3 \\
\hline Trunk pipe length (m) & 19.52 & 19.52 & 19.52 \\
\hline Reticulation pipe length (m) & $3,622.91$ & $3,616.06$ & $3,223.34$ \\
\hline Service pipe length $(\mathrm{m})$ & $1,668.58$ & $1,663.49$ & $1,648.46$ \\
\hline $\begin{array}{l}\text { Total head loss due to friction in trunk, reticulation and } \\
\text { service pipelines }(\mathrm{m})\end{array}$ & $62,306.70$ & $62,165.75$ & $59,364.58$ \\
\hline $\begin{array}{l}\text { Total head loss based on local resistance coefficients } \\
\text { trunk, reticulation and service pipelines }(\mathrm{m})\end{array}$ & $1,578.20$ & $1,567.45$ & $1,568.33$ \\
\hline Pressure drop in trunk and reticulation pipes $(\mathrm{kPa})$ & 82.54 & 85.13 & 67.84 \\
\hline
\end{tabular}


plan," Journal of Energy in Southern Africa, vol. 25, no. 3, pp. 67-73, 2014.

[16] (2012, November) Installation and maintenance manual for cocinas cristal-gas cg.1 $4 \mathrm{~g}$ model gas burner. Teka eka Industrial S. A Limited. [Online]. Available: https://teka.com

[17] I. Ozigis, S. O. Oodo, and N. Lawal, "Design of an anaerobic digester for generation of biogas fired in a burner and lamp," FUOYE Journal of Engineering and Technology, vol. 4, no. 1 , pp. 52-57, 2019

[18] H. Sidrouhou, M. Korichi, and S. Dada, "Evaluation of correlations of compressibility factor $(\mathrm{z})$ of natural gas for algerian gas reservoirs," in Energy Procedia 157, 2019 , pp. 655-669.

[19] R. Khadzhikov and S. Butakov, Designing Water Pump Plants. Mining Mechanical Engineering. Moscow: Mir Publishers, 1988.

[20] F. White, Fluid Mechanics, 7th ed. New York: McGrawHill, 1988.

[21] R. Rajput, Fluid Mechanics and Hydraulic Machines, 5th ed. New Delhi-110 055: McGraw-Hill, 2011.

[22] (2019, September) Storage vessel specification sheet. [Online]. Available: https://www.camgas.co.uk/pdf/ Above-ground_Tech_Specification_Sheet

\section{Appendix A. Tables}

Table A.13: Properties of the LPG (propane) [9]

\begin{tabular}{lll}
\hline S/No & Description & Value \\
\hline 1 & Chemical formula (propane) & $\mathrm{C}_{3} \mathrm{H}_{8}$ \\
2 & Density of liquid propane & $493 \mathrm{~kg} / \mathrm{m}^{3}$ \\
3 & Absolute viscosity & $7.4 \mathrm{Poise}$ \\
4 & Specific gravity & 1.52 \\
5 & Molecular weight & $44.097 \mathrm{~kg} / \mathrm{kmol}$ \\
6 & Propane ignition tempera- & $470^{\circ} \mathrm{C}-550^{\circ} \mathrm{C}$ \\
& ture in air & \\
7 & Specific heat & $1630 \mathrm{~J} / \mathrm{kg} / \mathrm{K}$ \\
8 & LPG normal temperature & $20^{\circ} \mathrm{C}$ \\
9 & LPG normal pressure & $101.325 \mathrm{kPa}$ (at \\
& & $\left.20^{\circ} \mathrm{C}\right)$ \\
10 & Propane flame temperature & $1,967{ }^{\circ} \mathrm{C}$ \\
11 & Energy content of LPG & 25 \\
& & $91,547 \mathrm{BTU} / \mathrm{Lal}$ \\
& & $\left(60^{\circ} \mathrm{F}\right)$ \\
12 & Heat of combustion & $50340 \mathrm{~kJ} / \mathrm{kg}$ \\
13 & Gas constant (R) & 188 \\
14 & Gas compressibility factor & 0.998 \\
& (Z) &
\end{tabular}

Table A.14: Characteristics of LPG gas burner [14]

\begin{tabular}{|c|c|c|c|c|}
\hline S/No & Description & Unit & $\begin{array}{l}\text { G- } \\
\text { 30/G31 }\end{array}$ & $\begin{array}{l}\text { G- } \\
\text { 30/G31 }\end{array}$ \\
\hline 1 & Bur & & Standard & Small \\
\hline 2 & Mod & & $\begin{array}{l}\text { Semi } \\
\text { fast }\end{array}$ & $\begin{array}{l}\text { Auxiliary } \\
\text { burner }\end{array}$ \\
\hline 3 & $\begin{array}{l}\text { Calorific value } \\
\text { consumption }\end{array}$ & $\mathrm{kcal} / \mathrm{hr}$ & 1500 & 860 \\
\hline 4 & $\begin{array}{l}\text { Inlet gas pres- } \\
\text { sure }\end{array}$ & (mbar) & $28-37$ & $28-37$ \\
\hline 5 & $\begin{array}{l}\text { Pan Size diame- } \\
\text { ter }\end{array}$ & $\mathrm{mm}$ & 140 & 140 \\
\hline 6 & $\begin{array}{l}\text { Gas consump- } \\
\text { tion }\end{array}$ & $\mathrm{kg} / \mathrm{hr}$ & 0.13 & 0.07 \\
\hline 7 & Nozzle diameter & $\mathrm{m}$ & & \\
\hline 8 & Hea & $\mathrm{kV}$ & $1.75 \mathrm{~kW}$ & $1.0 \mathrm{~kW}$ \\
\hline 9 & Efficiency & & $>52^{c}$ & $>52 \%$ \\
\hline
\end{tabular}

\section{Appendix B. Calculations}

Appendix B.1. Gas velocities in the reticulation pipelines

The gas velocity in the reticulation pipelines was computed using a variation of Eq. (4) [18]:

$$
V_{R}=\frac{4 Q_{P}}{\pi} d_{R}^{2}
$$

\section{Appendix B.2. Gas velocity in the service pipelines}

The gas velocity in the service pipelines was calculated using a variation of Eq. (4) [18]:

$$
V_{s}=\frac{4 Q_{P}}{\pi} d_{s}^{2}
$$

\section{Appendix B.3. Gas mass flow rate in the} reticulation pipe sections

The gas mass flow rate in the reticulation pipelines $\left(m_{R}\right)$ was computed using Eq. (5) [19]:

$$
m_{R}=\rho A_{R} V_{R}
$$

\section{Appendix B.4. Gas mass flow rate in the ser-} vice pipe sections

The gas mass flow rate in the service pipelines $\left(m_{s}\right)$ was computed using Eq. (5) [19]:

$$
m_{s}=\rho A_{s} V_{s}
$$

\section{Appendix B.5. Head loss based on local resis- tance coefficients in the retic- ulation pipeline}

The head loss on local resistance coefficients in the reticulation was computed using Eq. (7) [19]:

$$
\Sigma h_{R}=\left(\lambda_{R} \frac{l_{R}}{d_{R}}+\Sigma \varsigma\right) \frac{V_{R}^{2}}{2 g}
$$

\section{Appendix B.6. Head loss based on Local resistance in the service pipeline (Options 1, 2 and 3)}

The head loss based on local resistance coefficients in the service pipeline utilized using Eq. (7) [19]:

$$
\Sigma h_{s}=\left(\lambda_{s} \frac{l_{s}}{d_{s}}+\Sigma \varsigma\right) \frac{V_{s}^{2}}{2 g}
$$

\section{Appendix B.7. The pump head was estimated} using Eq. (B.1) [18]

$$
H=H_{e l}+\Sigma h
$$

Where $H$ is the Pump head (m), $H_{e l}$ is the elevation head $(\mathrm{m})$ and $\Sigma h$ is the sum of head losses on based local resistance in the service, reticulation and trunk pipe sections.

Appendix B.8. The motor power was computed using Eq. (B.2) [18]

$$
M_{p}=\frac{Q_{p} \rho g H}{1000 \eta}
$$

where $\eta$ is efficiency of the pump, $\rho$ is density of the gas, $g$ is the acceleration due to gravity, $Q_{p}$ is the Gas demand in $\mathrm{m}^{3}$ /hour, $H$ is the Pump Head (m). 